\title{
Kernos
}

Revue internationale et pluridisciplinaire de religion grecque antique

$15 \mid 2002$

Varia

\section{"Either a Daimon, or a Hero, or Perhaps a God:" Mythical Residents of Subterranean Chambers}

\section{Yulia Ustinova}

\section{(apenEdition \\ Journals}

Electronic version

URL: http://journals.openedition.org/kernos/1385

DOI: 10.4000/kernos. 1385

ISSN: 2034-7871

\section{Publisher}

Centre international d'étude de la religion grecque antique

\section{Printed version}

Date of publication: 1 January 2002

ISSN: 0776-3824

\section{Electronic reference}

Yulia Ustinova, «"Either a Daimon, or a Hero, or Perhaps a God:" Mythical Residents of Subterranean Chambers ", Kernos [Online], 15 | 2002, Online since 21 April 2011, connection on 01 May 2019. URL: http://journals.openedition.org/kernos/1385; DOI : 10.4000/kernos.1385 


\section{"Either a Daimon, or a Hero, or Perhaps a God:" Mythical Residents of Subterranean Chambers}

In his list of seers who uttered gods' orders and messages to mortals not only when alive, but also after their death, Strabo" mentions "...Amphiaraos, Trophonios, Orpheus, Musaios, and the god of the Getae, formerly Zalmoxis, a Pythagorean, who is in our time Dekaineos, the diviner of Byrebistas..." Aristides groups together Trophonios, Amphiaraos, Amphilochos and the Asclepiads. ${ }^{3}$ Celsus includes Zalmoxis, Mopsos, Amphilochos, Amphiaraos, and Trophonios in his register of mortals who died and were nevertheless worshiped, which makes Origen wonder, "whether one of these is either a

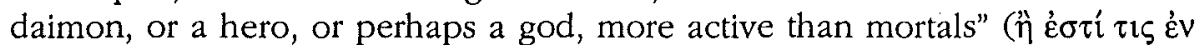

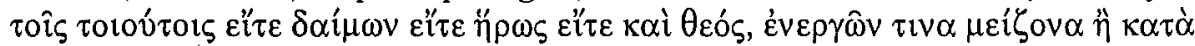
$\ddot{\alpha} v \theta \rho \omega \pi \mathrm{ov} ;){ }^{4}$ The bewilderment of Origen is reasonable, given the elusiveness of these figures. Celsus observes that these daimonia, who "settling in a certain place, live there," are in fact "gods in human form." The juxtaposition of oracle givers, heroes, philosophers and barbaric prophets contains an insight into some fundamental features shared by these characters.

In addition to vatic talents, common to all the mythical figures in these lists, Zalmoxis, Dekaineos, Amphiaraos, and Trophonios are singled out by their exceptional mode of existence: still alive, they descended below the earth, and continued their involvement in the life of mortals, remaining invisible to human eyes. Greek mythology supplies further instances of lonely underground dwellers, who were neither mortals nor gods. The location of their subterranean abodes is noteworthy: almost all of them are positioned in the Northern and Central Balkans. The present article is an attempt at a definition of this cult type and an interpretation of its peculiar traits.

1 XVI, 2 39, following Posidonios of Apamea (FGrH 87 F 70 Jacoby).

2 This list is preceded by Teiresias (MEINEKE, Strabonis Geographia, Leipzig, 1877, deletes the passage on Teiresias), and followed by Achaicaros of the Bosporus (a mysterious bapax), Indian Gymonosophists and other fortune-tellers, but it forms a distinct phrase, clearly separated from the rest of the passage.

3 Orat. XXXVIII, 21.

4 Contra Cels. III, 34-35.

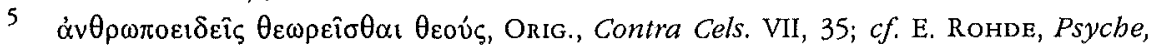
Translated by W. B. Hillis, London, 1925, p. 104. 


\section{Boeotia}

\section{Amphiaraos}

Amphiaraos, a famous seer, and a descendant of the prophet Melampous, was believed to have been swallowed by the earth when he fled from Thebes. The chasm was opened before Amphiaraos by Zeus, who saved him from the imminent death in the hands of his foes, and made him immortal. ${ }^{6}$ The name means either "prayed to, entreated on all sides," or "cursing on all sides" - an ambiguity befitting a daimon that can both inflict a disease and cure it. ${ }^{7}$

Although Amphiaraos' most famous oracle was in Oropos, ${ }^{8}$ it was also said that he had a shrine near Thebes. ${ }^{9}$ The Theban oracle of Amphiaraos is reported by Herodotus to be one of the most prominent oracles in Greece, and to have been consulted by Croesus and Mys. ${ }^{10}$ Several cities of Boeotia rivaled for the honor to be recognized as the true place of Amphiaraos' disappearance. ${ }^{11}$ It is suggested that the Oropian shrine emerged after the decline of Boeotia and its sanctuaries during the Persian war. ${ }^{12}$ The alternative view, that the oracle at Oropos is the original and only Amphiaraion, ${ }^{13}$ is more probable, since the deity was conceived as physically present in his cult place. In any case, in the fifth century the Amphiaraion at Oropos was a most popular healing oracle; inscriptions and dedications of models of various parts of the body testify to its curative powers. ${ }^{14}$

The consultation, at least since that period, was by incubation on ram skins, ${ }^{15}$ while patients were visited in their sleep by the seer in person: ${ }^{16}$ there is no mention of a prophet in the evidence on Amphiaraion. ${ }^{17}$ A fourthcentury relief dedicated to Amphiaraos portrays a patient in two attitudes:

6 PIND., Nem. IX, 24-27; X, 8-9; an epic fragment, perhaps originating in the Thebaid (fr. 9 Davies); Eur., Suppl., 926; Paus., I, 34, 1; Apollod., III, 6, 8. There is iconographic evidence, as well: I. Krauskopf, "Amphiaraos," IIMC I (1981), Nos. 37-41, 44-46. See RoHDE (cit. n. 5), p. 89-90; T.K. HubBARD, "Cult Tradition in Pindar's Ninth Nemean," HSPb 94 (1992), p. 102. In the Odyssey (XV, 243-347) Amphiaraos is killed at Thebes.

7 A. Carnoy, "Les noms grecs des devins et magiciens," LEC 24, 2 (1956), p. 102, interprets Amphiaraos' name as "l'homme aux imprécations et paroles sacrées."

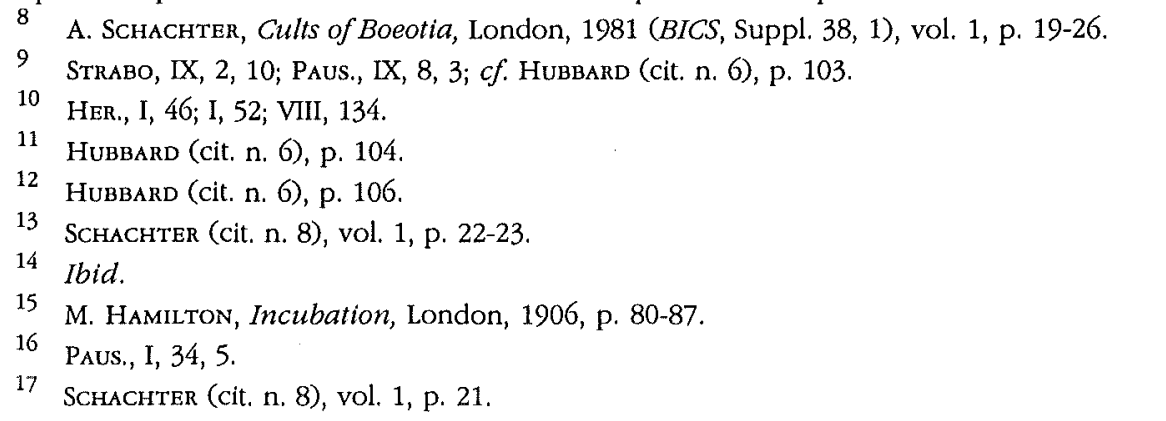


sleeping, his arm licked by a serpent, and treated by the hero himself. ${ }^{18}$ Incubation on ram skins is known in dream oracles of Calchas and Podaleirios in Apulia, ${ }^{19}$ in the late fifth century it appeared in the Attic Asclepeia, where it is attested by several reliefs. ${ }^{20}$ Animal hides were used not only for the purposes of learning the future and in iatromancy, but also in magic, especially in weather magic, ${ }^{21}$ and as means of purification. ${ }^{22}$

Before the incubation, the consultant had to purify himself, to fast, ${ }^{23}$ and to sacrifice to Amphiaraos and to a number of gods and heroes, whose names were inscribed on Amphiaraos' altar. This list, which includes Apollo Paian, Panacea, Iaso, Hygeia, and Athena Paionia, ${ }^{24}$ gives emphasis to the healing aspect of the Oropian oracle. Like Asclepios, Amphiaraos was connected with snakes. ${ }^{25}$

Amphiaraos is normally considered a hero, but occasionally he is called god. This controversy was solved, at least legally, by the Romans, who declared him a god for tax purposes. ${ }^{26}$ Amphiaraos' son Amphilochos inherited his father's powers and rivaled Mopsos as a seer. Like his father, Amphilochos appeared in person to inquirers in his dream-oracles at Mallos in Cilicia and in Acarnania. ${ }^{27}$

\section{Trophonios $^{28}$}

18 Krauskopf (cit. n. 6), No. 63.

19 STrABo, VI, 3, 9; Lycophr., 1047-1051 with schol.

20 A. Petropoulou, "Pausanias 1.34.5: Incubation on a Ram Skin," Colloques internationaux du CNRS "La Béotie antique." Paris, 1985, p. 170-175.

21 S. ErTREM, Opferritus und Voropfer der Griechen und Römer, Kristiania, 1915, p. 372379; B.K. Braswell, A Commentary on the Fourth Pythian Ode of Pindar, Berlin, 1988, p. 318.

22 Dios kodion, Suda s.v. Aiò kúdiov; J.E. Harrison, Prolegomena to the Study of Greek Religion, Cambridge, 1928, p. 23-28; Petropoulou (cit. n. 20), p. 177.

23 Philostr., Vita Apoll. II, 37. On the importance of fasting for provoking "divine" dreams, see E.R. DodDs, The Greeks and the Irrational, Berkeley, 1951, p.110.

24 PAUS., I, 34, 3.

25 Schachter (cit. n. 8), vol. 1, p. 23.

26 CIC., De nat. deorum III, 19.

27 Lucian., Alexandros, 19, 29; Orig., Contra Cels. III, 35.

28 In recent years, a most systematic and profound research on Trophonios is carried out by P. Bonnechere: P. and M. Bonnechere, "Trophonios à Lebadée. Histoire d'un oracle," LEC 67 (1989), p. 289-302; P. Bonnechere, "Les dieux du Trophonion lébadéen : panthéon ou amalgame?," Kernos Suppl. 8 (1998), p. 91-108; "La scène d'initiation des Nuées d'Aristophane et Trophonios : nouvelles lumières sur le culte lébadéen," REG 111 (1998), p. 436-480; "La personnalité mythologique de Trophonios," RHR 216 (1999), p. 259 297. I am very grateful to P. Bonnechere for having kindly sent to me his yet unpublished book on Trophonios. 
Trophonios, ${ }^{29}$ whose oracle was in Lebadea, ${ }^{30}$ was also believed to have been swallowed there by the earth. Since then, he lived in a cave under a hill as an oracular god. ${ }^{31}$ Both in literary and in epigraphic sources, the act of consultation of the oracle is described as $\kappa \alpha \tau \alpha \beta \beta \alpha \sigma \iota$, or by means of other derivatives from $\kappa \alpha \tau \alpha \beta \alpha i v \omega$ or $\kappa \alpha \tau \varepsilon$ é $\chi \circ \mu \alpha \iota,{ }^{32}$ whereas the place of the oracle

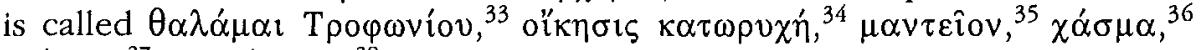
$\sigma \tau$ ó $\mu$ เov, ${ }^{37}$ or $\sigma \pi \eta \dot{\eta} \lambda \alpha$ เov. ${ }^{38}$

Trophonios himself is regarded as a god, rather than a hero. ${ }^{39}$ The oracle in Lebadea existed by the sixth century. Even if Croesus' and Mys' consultations of Trophonios ${ }^{40}$ are legendary, the oracle is mentioned frequently enough in the fifth-century Attic drama, ${ }^{41}$ and Athenian public was familiar with the procedure of katabasis to Trophonios' cave. ${ }^{42}$ Trophonios is mentioned in the sixth-century Telegony, and by Pindar. ${ }^{43}$ The procedure of the oracle is described in detail by Pausanias: ${ }^{44}$ having offered preliminary sacrifices, the consultant descended to Trophonios' cave. The symbolism of the Trophonion was that of the underworld: the consultant was led by two boys called Hermai, and was allowed the access to the oracle only after he had drunken from the water of Lethe and Mnemosyne. ${ }^{45}$

29 The name derives probably from $\tau \rho \circ \varphi-/ \tau \rho \varepsilon \varphi-, O$. Gruppe, "Trophonios," Roscher V (1916-24), p. 1270; Schachter (cit. n. 8), vol. 3, p. 71. G. RAdKe ("Trophonios," RE VII A 1 [1939], col. 639) and SCHACHTER (o.c., vol. 3, p. 72) suggest that it may also result from a phonetic adaptation of a non-Greek name.

30 For the oracle and its history, see Gruppe (cit. n. 29); Radke (cit. n. 29); SCHACHTER (cit. n. 8), vol. 3, p. 66-89; "A Consultation of Trophonios (IG 7.4136)," AJPb 105 (1984), p. 258-270; “A Boeotian Cult Type," BICS 14 (1967), p. 1-16; RJ. Clark, "Trophonios: The Manner of His Revelation," TAPbA 99 (1968), p. 63-75.

31 PAus., IX, 37, 3.

32 Aristoph., Nub., 508; Her., VIII, 134; Semos of Delos, FGrH 396 F 10 Jacoby (in Athen., XIV, 614a); Paus., IX, 39; $l G$ VII, 4136, c $f$. Schachter, "A Boeotian Cult ..." (cit. n. 30), note 11; id. (cit. n. 8), vol. 3, p. 80; Bonnechere, "La scène..." (cit. n. 28), p. 445.

33 EUR., ION, 394

34 Charax, FGrH $103 \mathrm{~F} 5$ Jacoby.

35 STRABO, DX, 2, 38.

36 Strabo, IX, 2, 8.

37 Lucinn., Dial. Mort., 3; Menipp., 22.

38 Lucian., Dial. Mort., 3; cf. RAdKe (cit. n. 29), col. 685; Schachter (cit. n. 8), 3, p. 75.

39 Schol. Aristoph., Nub., 508; cf. Schach'ter (cit. n. 8), vol. 3, p. 71.

40 Her., I, 46; VII, 134.

41 E.g. Aristoph., Nub., 508; Eur., Ion, 300-302, 404-409.

42 RADKe (cit. n. 29), col. 682; Bonnechere "Les dieux ..." (cit. n. 28), p. 100.

43 Fr. 3 Maehler, in Plut, Consol. Apoll., 109a.

44 IX, 39, 4-5, cf. Philostr., Vita Apoll. VIII, 19. For the site, see Schachter (cit. n. 8), vol. 3, p. 72-79; Bonnechere, "Les dieux ..." (cit. n. 28), p. 91-96.

45 Schachter (cit. n. 8), vol. 3, p. 82-83; Bonnechere, "Les dieux ..." (cit. n. 28), p. 101, id., "La personnalité..." (cit, n. 28), p. 268. 
However, it is to be borne in mind that since Trophonios dwelled alive in his subterranean abode, the katabasis into the cave was not completely equal to a journey to Hades.

The consultant had to bring with him honey cakes for the snakes waiting for him at the bottom of the cave. ${ }^{46}$ Immediately following his stay in the underground cave, the inquirer was to take a seat on the chair of Mnemosyne and to retell his experience to the priests; only after this procedure the suppliant, semi-conscious and paralyzed with terror, was allowed to be taken away by his relatives. ${ }^{47}$

Trophonios was believed to appear to the inquirers in person. ${ }^{48}$ The consultant's experience in the Trophonion is described by Plutarch's The Daimonion of Socrates. ${ }^{49}$ This fascinating testimony recounts the communication of a young man named Timarchos, who spent in the cave two nights and a day, in a world beyond normal experience. In a sleep or in trance, ${ }^{50}$ his soul flew above an ocean with shining isles, ${ }^{51}$ and in a mixture of joyfulness and awe Timarchos heard voices that explained to him the mystery of metempsychosis and predicted his near death. In this vision, culturally structured patterns, such as mythical geography of the netherworld, as well as the notions of soul, its liberty and need of purification, are interwoven with phenomena characteristic of altered states of consciousness, ${ }^{52}$ such as lack of awareness of the surroundings, feeling of unearthly happiness, visual and auditory hallucinations. ${ }^{53}$ To achieve this state, the suppliant needed neither gaseous inhalations nor an interference of any other factors in addition to his being alone in awe-inspiring surroundings. ${ }^{54}$

46 Aristoph., Nub., 506-508 with schol,; Lucian., Dial. mort., 3; Paus., IX, 39, 11; Philostr., Vita Apoll. VIII, 19.

47 Paus., LX, 39, 13.

48 Maxim. Tyr., Dissert. VIII, 2; Orig., Contra Cels. III, 34, cf. Rohde (cit. n. 5), p. 105; P. and M. Bonnechere (cit. n. 28), p. 291; SCHACHTER (cit. n. 8), vol. 3, p. 80.

49 21-22, 509b-592f.

50 J. HANi, "Le mythe de Timarque chez plutarque et la structure de l'extase," $R E G 88$ (1975), p. 110; ClarK (cit. n. 30), p. 64, 70.

51 On the mystical light appearing to the sleepers, and voices heard in dreams, as described in Aristides' Orations, see Hamilton (cit. n. 15), p. 4-5.

52 For altered states of conscience in the Greek culture and a comparison with the anthropological evidence, see Yu. Ustinova, "Corybantism: The Nature and Role of an Ecstatic Cult in the Greek Polis," Horos 10-12 (1992-98), p. 503-520.

53 Cf. Paus., IX, 39, 11: those who are inside the adyton, learn the future not in the same way, but by sight sometimes and at other times by hearing, cf. CLARK (cit. n. 30), p. 70 .

Contrary to the views of HAMILTON (cit. n. 15, p. 89), Clark (cit. n. 30), p. 73, and SCHACHTER (cit. n. 8, vol. 3, p. 83). On the phenomenon of self-inflicted trance, see HaNi (cit. n. 50). For an analysis of the proceedings in the Trophonion in terms of Jung's psychology, see C.A. MEIER, Antike Inkubation und moderne Psychotherapie, Zürich, 1949, p. $87-111$. 
For the purposes of the present discussion, Timarchos' historicity as a person is insignificant: ${ }^{55}$ the most substantial inference from Plutarch's description is that in his time at the latest an inquirer in the Trophonion experienced an altered state of consciousness, accompanied by culturally patterned visions. A major source of The Daimonion of Socrates was Plato's Pbaedon, ${ }^{56}$ whereas a number of Plato's works are saturated with references to altered states of consciousness. ${ }^{57}$ Moreover, as P. Bonnechere demonstrates, ${ }^{58}$ in Atistophanes' Clouds, where the action in Socrates' frontisterion is compared to a katabasis to the Trophonion, several passages hint at phenomena apparently very similar to those mentioned by Plutarch, such as the opposition of memory and oblivion, independence of soul, and its levitation. ${ }^{59}$ It is therefore reasonable to assume that altered states of conscience were experienced in the Trophonion as early as in the fifth century.

Trophonios and his brother (or stepfather) Agamedes were legendary architects, whose works included the lower courses of Apollo's Delphic temple (or probably its adyton ${ }^{60}$ ) and other masterpieces. ${ }^{61}$ Most structures were secret chambers, such as treasuries and the thalamos of Alcmene, ${ }^{62}$ closed to all but a few humans, and visited by gods, Zeus and Apollo. As Bonnechere demonstrates, supernatural features of these constructions, where encounters between the human and the divine took place, disclose their builders' magic nature. ${ }^{63}$ Although said to be the son of Apollo, ${ }^{64}$ Trophonios was usually considered the son of Erginos of Orchomenos. ${ }^{65}$ The name Erginos, if it derives indeed from है $\rho \gamma o v,{ }^{66}$ fits a father of a famous craftsman so well that one suspects an invention of the industrious father to provide a suitable genealogy for the son. ${ }^{67} \mathrm{~A}$ statue of Trophonios sculptured

55 Cf. Bonnechere, "La scène..." (cit. n. 28), p. 449, with bibliography.

56 D. BABUt, "Le dialogue de Plutarque 'Sur le démon de Socrate.' Essai d'interprétation," $B A G B$ (1984), p. 51, 72; BONNECHERE, o.c., p. 452-453.

57 Ustinova (cit. n. 52), p. 508-509, with refs.

58 BONNECHERE, "La scène..." (cit. n. 28).

59 Verses 508, 483-485, 227-230, 319.

60 Radke (cit. n. 29), col. 679; Bonnechere, "La personnalité... (cit. n. 28), p. 269-275.

61 For the list of their works, see Gruppe (cit. n. 29), col. 1266-67.

62 PAus., IX, 11, 1.

63 Bonnechere, "Les dieux..." (cit. n. 28), p. 97; "La personnalité... (cit. n. 28), p. 280.

64 In the Pseudo-Hesiodic Catalogue of Women (M.L. WEST, "The Hesiodic Catalogue: New Light on Apollo's Love-Life," ZPE 61 [1985], p. 1, 6), as well as in PAus., IX, 37, 3 and other sources. H. GrégoIre, Asclèpios, Apollon Smintbeus et Rudra, Bruxelles, 1949 (Académie Royale de Belgique. Mémoires 45), p. 98, ascribes this connection to Apollo's immense popularity in Boeotia.

65 For Trophonios' genealogy, see Gruppe (cit. n. 29), col. 1266; Bonnechere, "La personnalité... (cit. n. 28), p. 290-297.

66 Grégorre (cit. n. 64, p. 100) connects it with Ergen, a Thracian river-name.

67 RADKE (cit. n. 29), col. 679. 
by Daidalos stood near the entrance to Trophonios' cave. ${ }^{68}$ The analogy between the two masters is significant. Daidalos, himself "the Cunning Artist," not unlike Trophonios, had parents bearing befitting noms parlants, Eupalamos, or Palamon, and Phrasimede. ${ }^{69}$ In Charax' narration, ${ }^{70}$ Daidalos was summoned by Augias to trap the thieves, and was outwitted by Trophonios, which implies Trophonios' victory in craft over Daidalos. To be sure, Daidalos' mythical biography reveals numerous shamanic features, ${ }^{71}$ and the work of an expert artisan in traditional societies was considered magical. Thus, Trophonios' architectural accomplishments hint at his vocation as a magician.

Pausanias ${ }^{72}$ tells the story of a trick used by the brothers while building the treasury of Hyrieus, which proved to be fatal for them. Using this trick, they kept entering the treasury and stealing from it. When finally Agamedes was trapped, Trophonios was forced to kill him, lest the identity of the thieves be disclosed. The earth swallowed Trophonios up in Lebadea, at the point where in Pausanias' time was the bothros of Agamedes. In another version of 'Trophonios' death, presumably providing a "civilized" explanation for a bizarre phenomenon, Trophonios descended to a subterranean dwelling, vं ó $_{\varepsilon \varepsilon 10 v}$ oik $\eta \mu \alpha$, because of his ambition or vanity, ${ }^{73}$ wishing to hide his remains and thus to make people believe that he became a god. ${ }^{74}$

This myth recorded by Pausanias is a clone of the legend of Rhampsinitos in the Egyptian logos of Herodotus. ${ }^{75}$ It also has numerous less exact parallels in the folklore of all parts of the world, ${ }^{76}$ and could have been easily adopted for local needs. Trickery and magic art are indeed intimately connected, therefore the story stuck to Trophonios, and had a version with Augias in

68 Paus., IX, 39, 4; 40, 3.

69 Paus., IX, 3, 2; Diod. IV, 76; Apollod., III, 15, 9; Hygin., Fab., 39; cf. F. FrontisiDucroux, Dédale, Paris, 2000, p. 89-94 on Daidalos' parents; ibid., p. 186-188 on the parallelism between Daidalos and Trophonios.

70 FGrH 103 F 5 Jacoby, in Schol. ARistopH., Nub., 508.

71 Such as his possession of the secret of the Labyrinth, his role as an instructor in initiation rites of youths, his magic flight, etc. (Yu. V. ANDreyev, Poeziya mifa $i$ proza istorii [Poetry of Myth and Prose of History], Leningrad, 1990, p. 74-91). On Daidalos as a magician, cf. M. Delcourt, Héphaistos ou la légende du magicien. Paris, 1957, p. 158.

$72 \mathrm{IX}, 37,3$.

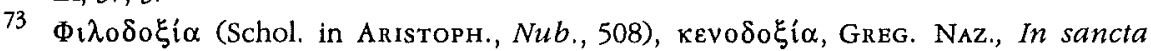
lumina, Migne 36 col. 340; Schol, in Lucian., Dial. Mort., 10. Cf. Radke (cit, n. 29), col. 681

74 Contrary to these writers, PINDar (fr. 3 Maehler, cit. n. 43) asserts that Trophonios and Agamedes were granted death by Apollo as a reward for the construction of the temple in Delphi. $C f$. Bonnechere, "La personnalité..." (cit. n. 28), p. 263-269.

75 II, 121 .

76 W.W. How, J. Wells, A Commentary on Herodotus, Oxford, 1928, vol. 1, p. 225; W. ALY, Volksmärchen, Sage und Novelle bei Herodot und seinen Zeitgenossen. Göttingen, 1969, p. 67. See however Grégorre (cit. n. 64, p. 105) on Hyrieus as an eponym of Boeotian Hyrie. 
Hyrieus' stead. ${ }^{77}$ In any case, vanishing under the earth does not result from the preceding stages of Pausanias' story: one can imagine a different ending, such as a punishment for fratricide or a continuation of Trophonios' career. This discontinuity indicates perhaps that a migrant subject of ruse was attached to a prescribed end. In fact, in Charax' version Trophonios hid in an underground shelter, and lived there till his death; it was only after his death that the oracle was founded. The tales of both Trophonios' and Amphiaraos' disappearance under the earth are far from being heroic. The invention of the unflattering etiological myths seems to have been necessary in order to account for the hero's subterranean dwelling.

Pausanias compares Trophonios with Asclepios. In the sanctuary at Lebadea there was a statue of Asclepios and Hygeia, which could be taken as representing Trophonios and his daughter Hercyna: both pairs had snakes as their attributes. A statue of Trophonios himself, executed by Praxitiles, resembled Asclepios. ${ }^{78}$ Moreover, it was said that Trophonios, like Asclepios, could appear in the shape of a snake. ${ }^{79}$ The proximity between Trophonios and Asclepios is implied by the authors giving them the same father, either Apollo, or Ischys. ${ }^{80}$ Noteworthy, after Trophonios had been swallowed by the earth and his brother perished, the throne of Orchomenos passed to Ascalaphos and Ialmenes, ${ }^{81}$ the former name being probably a version of "Asclepios."

In the oracles at Oropos and in Lebadea the consultant received the response directly from the hero, whom he saw in a dream or in a revelation. The Amphiaraion and the Trophonion share this feature with the dream oracles of Asclepios. Moreover, the oracle of Amphiaraos was considered a iatromanteion, while at least in one instance Trophonios is attested to be regarded a proper address to ask a question concerning a couple's barrenness. ${ }^{82}$ Greek healing was indeed interwoven with divination, as countless instances of cleansing areas from epidemics by seers, as well as the practice of incubation in Asclepieia, demonstrate. ${ }^{83}$

77 ChARAx, FGrH 103 F 5 Jacoby. Since a crater featuring "the history of Trophonios, Agamedes and Augias" is mentioned in the Telegony, this version dates back to the sixth century (BONNECHERE, "La personnalité..., cit. n. 28, p. 276, 289).

78 PAus., IX, 38, 2-3.

79 Schol. Aristoph., Nub., 508; RAdKe (cit. n. 29), col. 689. On serpents brought as Asclepios to the god's newly founded sanctuaries, see Paus., II, 10, 3; IG $\mathrm{II}^{2}, 4960$, LIV., Epit., 10. Cf. W.S. Ferguson, "The Attic Orgeones," HTbR 37, 2 (1944), p. 86-91.

${ }^{80}$ CICERo (De natura deorum III, 22) asserts that the two heroes were sons of Valens (i.e. Ischys) and Coronis, that is, brothers.

81 Paus., IX, 38, 3; Grégolre (cit. n. 64), p. 102.

82 Eur., Ion, 392-409; P. and M. BonNechere (cit. n. 28), p. 295.

83 Hamilton (cit. n. 15), passim. 


\section{Thessaly}

\section{Asclepios}

A katabasis to the adyton was performed by the consultant in the Asclepeion in Tricca, the most ancient of all Asclepios' sanctuaries. ${ }^{84}$ In the Iliad Asclepios' sons are depicted as leaders of forces from Tricca and Ithome (in Thessaly) and Oichalia (in Aetolia) ${ }^{85}$ Numerous details of Asclepios' birth legend that are limited to Thessaly, establish the status of this land as the cradle of Asclepios' myth and cult. ${ }^{86}$

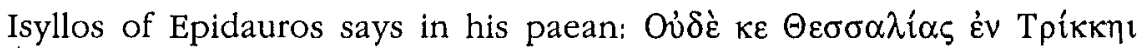

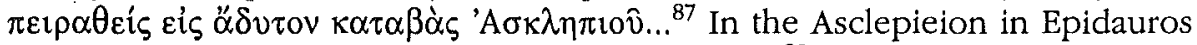
the inquirer saw and heard the god in his dreams; ${ }^{88}$ the contact between the inquirer and the god in the Asclepieion in Tricca was almost certainly imagined in the same way. As already mentioned above, the rites, iconography and sphere of competence of Trophonios and Amphiaraos closely resemble those of Asclepios. Homer regards Asclepios just as a leader of forces from Tricca, and does not recognize him as a god. In Tithoreia in

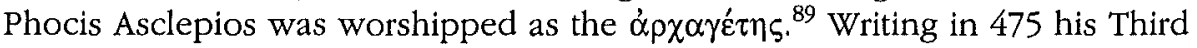
Pythian Ode, Pindar still considered Asclepios a hero, but in the second half of the fifth century the hero was promoted to the rank of a god. ${ }^{90}$ Yet Asclepios "is scarcely ever imagined in the company of other gods on Olympus," and "he belongs even less in the kingdom of the dead." ${ }^{11}$ He lives among men, present in the shape of a serpent.

The cult of Asclepios in Tricca features the same components as the cults of Trophonios and Amphiaraos: an oracle involving a katabasis and based on a direct contact between the deity and the inquirer, a cult of a local patron, with conspicuous chthonic elements, and a shift in the status of the personage from a mortal to a god.

84 StRABO, LX, 5, 17.
85 Il. II, 729-731.

86 GRÉGOIRE (cit. n. 64), p. 19-27; U. VON WILAMOWITZ-MÖLLENDORF, Isyllos von Epidaurus, Berlin, 1886, p. 54; Thraemer, "Asklepios," RE II 2 (1896), col. 1645; L. WEBER, "Asklepios, älteste Zeugnisse aus Thessalien und der Peloponnes," Pbilologus 87 (NF 41) (1932), p. 389-420; C. KerénYi, Asklepios. Translated by R. Manheim, New York, 1959, p. 87100; R. Martin, H. Metzger, La religion grecque, Paris, 1976, p. 70. For the arguments, ancient and modern, concerning Asclepios' place of origin, see E.J. \& L. Edelstein, Asclepius, Baltimore/London, 1998, vol. 2, p. 17-22, who close their discussion with a judgment in favor of Thessaly.

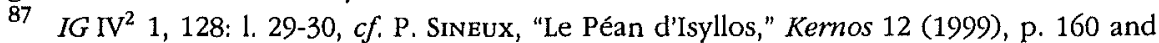
the paper by M.T. Molinos Tejada and M. Garcfi Teijeiro here (supra, p. 235-246).

88 E.g. Aristoph., Plutus, 708-711; IG IV ${ }^{2}$ 1, 121-122, 126; cf. EdELSTEIN (cit. n. 86), vol. 1, Nos. 414-454.

89 Paus., X, 32, 8; cf. Thraemer (cit. n. 86), col. 1646.

90 Edelstein (cit. n. 86), vol. 2, p. 66.

91 W. Burkert, Greek Religion. Translated by J. Raffan, Cambridge Mass., 1985, p. 214. 
However, an important mythological element, the disappearance beneath the earth, is absent: ancient authors are unanimous in ascribing Asclepios' death to Zeus' bolt of lightening. ${ }^{92}$ Moreover, we know nothing about dwelling of Asclepios in his shrine in Tricca, although such belief might ensue from the appearance of the god in person to the inquirers in his manteia. Thus, notwithstanding the common features, the cult of Asclepios in Tricca can be joined together with cults of subterranean daimons only with an important reservation.

\section{Kaineus}

Plutarch ${ }^{93}$ tells the story of Kaineus, a Thessalian Lapith, ${ }^{94}$ whom Poseidon had made invulnerable. Kaineus was attacked by Centaurs, but they were unable to wound him, and he sunk under the earth unwounded "after splitting the earth with his upright foot," 95 (that is, standing and alive). In another version, Centaurs who sealed Kaineus in the rock were sent by Zeus, wishing to punish Kaineus for his attempt to establish a cult of his spear. ${ }^{96}$ The latter detail indicates an extremely archaic cult, similar to the Scythian cult of the sword. ${ }^{97}$

The death of Kaineus is depicted in numerous works of art, starting from the second half of the seventh century BC: on a bronze relief from Olympia two Centaurs hammer an armed warrior into the ground. ${ }^{98}$ Kaineus' demise is also depicted on the François vase, on the friezes of the Hephaisteion in Athens, of the temple of Apollo at Bassai, and elsewhere. ${ }^{99}$

Only scraps of Kaineus' legendary biography have reached us. One of the few surviving episodes of his legend hints at his abilities as a prophet and sorcerer. Kaineus was said to have originally been a girl loved by Poseidon. Following her request, the god turned her into an invulnerable man. ${ }^{100}$ The change of the sex experienced by Teiresias, the famous seer, ${ }^{101}$ was known

\footnotetext{
92 Edelstein (cit. n. 86), vol, 1, Nos. 105-115.

93 Compend. ang. Stoic., $1057 \mathrm{~d}$.

94 Hom., Il. II, 746.

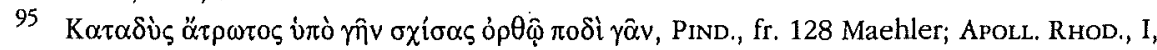
63-64; Hygin., Fab., 14.

96 Schol. Il. I, 264; Schol. Apol.t. Rhod., I, 57.

97 Her., IV, 62. Historical and anthropological parallels are collected in: S.S. Bessonova, "O kul'te oruzhiya u skifov" (On the Scythian Cult of Arms), in Y.V. Chernenko et al. (eds.), Vooruzbeniye skifov $i$ sarmatov (Scythian and Sarmatian Arms), Kiev, 1984, p. 3-21.

98 T. GANTz, Early Greek Myth, Baltimore/London, 1993, vol. 1, p. 280.

99 Seeliger, "Kaineus," Roscher, II, 1 (1890-94), p. 894.

100 Schol. Apoll. Rhod., I, 57; Schol. Il. I, 264; Hygin., Fab., 14.

101 Hom., Od. X, 487, with schol.
} 
already to Hesiod. ${ }^{102}$ In Herodotus' account, Scythian soothsayers, the androgynic Enareis, were endowed with the art of divination and afflicted with the "female sickness" by the same goddess, Aphrodite Ourania. ${ }^{103}$ K. Meuli has demonstrated the shamanic nature of Enareis, transsexuality being one of the elements of the shamanic complex. ${ }^{104}$ Thus, Kaineus' transsexuality suggests that like other characters whom the gods immersed under the earth, he possessed mantic powers. A cult of Kaineus ensues from his representation on coins of Gortyn, his native town. ${ }^{105}$

\section{Aristaios}

Aristaios, a hero of Thessalian origin, the son of Apollo, in Pindar's narration was made immortal by Horai who fed him with nectar and ambrosia. ${ }^{106}$ In Apollodoros' version, he grew up in Chiron's cave and learnt the art of medicine and divination from the Muses. ${ }^{107}$ Aristaios was also called Agreus and Nomios, ${ }^{108}$ sharing divine epithets with Apollo Agreus, Apollo Nomios, and Zeus Aristaios. ${ }^{109}$ Aristaios cleansed the Cyclades of a plague: following his father's command, he left Phthia, erected an altar on a mountain on Keos, and sacrificed to Zeus. ${ }^{110}$ Aristaios was also a legendary bee-keeper, ${ }^{111}$ whereas the association of bees with Apollo and divination is abundantly testified in myths: the second temple is Delphi was constructed of wax and feathers, ${ }^{112}$ and Trophonios' cave was discovered by the Boeotians following a swarm of bees. ${ }^{113}$ Later Aristaios joined Bacchos in

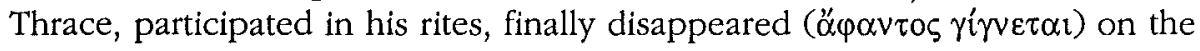

102 Fr. 275 Merkelbach-West in Apollod., III, 6, 7; cf. PAus., LX, 33, 1; Hygin., Fab., 75, cf. W. Burkert, Lore and Science in Ancient Pythagoreanism. Translated by E. L. Minar, Jr, Cambridge Mass., 1972, p. 163.

103 Her., IV, 67; I, 105, cf. [HIppocr.], De aere, 22. For discussion and bibliography, see Yu. Ustinova, The Supreme Gods of the Bosporan Kingdom, Leiden, 1999, p. 76-78.

104 K. Meuli, "Scythica," Hermes 70 (1935), p. 127-130; J.M. AtKinson, "Shamanisms Today," Annual Review of Antbropology 21 (1992), p. 318; D. Margreth, Skytbiscbe Schamanen? Die Nacbricbten über Enareis-Anarieis bei Herodot und Hippocrates, Schaffhausen, 1993, p.126; Ustinova, o.c., p. 78.

${ }^{105}$ F. STÄHLIN, Das bellenistische Thessalien, Stuttgart, 1924, p. 91.

106 PIND., Pyth. IX, 63-64.

107 APOLL. RHOD., II, 510-512.

108 Pyth. IX, 65.

109 Apol.t. RHOD., II, 506-507 with schol., Diod., IV, 81.

110 Apoll. Rhod., II, 518; Diod., IV, 82, cf. P. Philippson, Thessalische Mythologie, Zürich, 1944, p. 148-149.

111 Ver., Georg. IV, 317 sq.; Ovid., Pont. IV, 2, 9; Athen., XIV, 643b, Schirmer, "Aristaios," Roscher, I, 1 (1884-86), col. 548-550. On the symbolism of bees and apiculture see M. Detienne, "Orphée au miel," QUCC 12 (1971), p. 11-13.

112 Pind., fr. 52i Merkelbach-West; Paus., X, 5, 9-13. See C. Sourvinou-Inwood, "The Myth of the First Temples at Delphi," in Reading Greek Culture, Oxford, 1991, p. 196-200.

113 Paus., IX, 40, 1. 
Mount Haemus, and was thereupon honored as a god by both the Thracians and the Greeks. ${ }^{114} \mathrm{He}$ enjoyed heroic cults in Thessaly and Boeotia, as well as in Arcadia and in Sicily. ${ }^{115}$

\section{Thrace}

\section{Zalmoxis $^{116}$}

The main achievement of Asclepios, the "blameless physician," 117 was to make mortals immortal. In this respect, the mysterious cave-dwellers of Northern Greece remind of the Thracian underground daemons, who were believed to bestow immortality and to heal. In fact, Herodotus states thrice ${ }^{118}$ that the Getae, "the bravest and the most law-abiding of all Thracians," $\dot{\alpha} \theta \alpha v \alpha \tau i \zeta o v \sigma$, that is, "make themselves immortal." 119 He records at length the views of the Getae on immortality, his account concentrating on the figure of Salmoxis (other authors name him Zalmoxis or Zamloxis). ${ }^{120}$ Herodotus's information, Strabo's account of pious Thracians and their beliefs, as well as occasional references to Zalmoxis by other ancient authors and explanations of lexicographs, constitute the basis for a most vivid discussion of the subject by modern authors. ${ }^{121}$

114 DIOD., IV, 82.

115 Schirmer (cit. n. 111), col. 550.

116 The Greek knowledge of Thracian beliefs on immortality is discussed in my forthcoming paper (Yu. Ustinova, "Apollo Iatros: A Greek God of Pontic Origin," in K. StÄHLER and D. Metzler (eds.), Griechen und Nichtgriechen am Nordrand des Schwarzen Meers, Münster, in press).

117 Il. IV, 405; XI, 518.

118 IV, 93, 94; $\mathrm{V}, 4$.

119 This translation is much more accurate than "pretend" or "claim to be immortal" (e.g. in the Loeb translation of Herodotus by A.D. Goodley), see I.M. LinforTH, "Oi athanatizontes, Herodotus IV. 93-96," CPb 13 (1918), p. 23-33; F. PFISTER, "Zalmoxis," in G.E. Mylonas, D. Raymond (eds.), Studies Presented to D.M. Robinson, Saint Louis, 1953 vol. 2, p. 1113; M. Eliade, Zalmoxis. The Vanishing God. Translated by W. R. Trask, Chicago/London, 1970, p. 31; cf. N. VAN DER BEN, The Charmides of Plato: Problems and Interpretations, Amsterdam, 1985, p. 12: "to hold oneself immortal."

${ }^{120}$ Salmoxis in Herodotus; Zalmoxis in Plato, Diodorus, Apuleus, etc.; Zamolxis in Strabo, Lucian, Diogenes Laertius, etc. For the word and its etymology, obscure so far, see P. KRETSCHMER, "Zum Balkan-Skythischen," Glotta 24 (1936), p. 43-47; Pfister (cit. n. 119), p. 1113; D. Detschew, Die thrakischen Sprachreste, Wien, 1957, s.v. Zalmoxis; K. voN Fritz, "Zalmoxis," RE XVIII (1967), col. 2303; Eliade (cit. n. 119), p. 44-47; C. Poghirc, "Kulturelle Aspekte des thraco-dakischen Wortschatzes," in W. MeID (ed.), Studien zum Indogermaniscben Wortschatz, Innsbruck, 1987, p. 195.

${ }^{121} \mathrm{~W}$. Tомаsснек, "Die alten Thraker II," Sitzungsberichte der philologischbistorischen Klasse der Akademie der Wissenschaften in Wien 130 (1893), p. 62-67; ROHDE (cit. n. 5), p. 263-265; Pfister (cit. n. 119); R. CARpenter, Folk Tale, Fiction and Saga in the Homeric Epos, Berkeley, 1956, p. 112-135; Dodns (cit. n. 23), p. 144; J. Wiesner, Die Thraker, Stuttgart, 1963, p. 84-84; von FrITz (cit. n. 120); I.I. Russu, "Zalmoxis und die getodakische Religion," RE 18 (1967), col. 2303-2305; Eliade (cit. n. 119), p. 21-75; U. BianCHI, 
According to Herodotus, Getae believed that they did not die, but went to a daimon Zalmoxis. The Greeks who lived near Hellespont and the Pontus said that Zalmoxis had been a slave of Pythagoras. When he returned home to Thrace, he built a hall ( $\dot{\alpha} \nu \delta \rho \varepsilon \omega \dot{v}$ ), feasted there with most prominent of his countrymen, and taught that neither he nor they or their descendants would die, but go to a place where they live forever having all good things. In the meanwhile, Zalmoxis built himself an underground chamber ( $\kappa \alpha \tau \alpha \gamma \alpha$ tov oik $\eta \mu \alpha$ ), and descended into it for three years, the Thracians mourning him. In the fourth year he returned to them, making them believe the story he told.

Herodotus further reports that every four years the Getae send a messenger to Zalmoxis, ${ }^{122}$ by hurling him upon points. If the man is killed, they think that he is favored by the god. The story of Zalmoxis' return on the fourth year and the messenger's missions are closely connected: the messenger summons the god every fourth year to a ritual, which supposedly endows the worshipers with immortality. ${ }^{123}$

Plato discusses Zalmoxis in Cbarmides, ${ }^{124}$ and introduces a new aspect in the story: Thracian methods of healing. Socrates talks about approaches in medicine current in his days:

I learnt it (the charm) on campaign over there, from one of the Thracian physicians of Zalmoxis who are said to make themselves immortal ${ }^{125}$ ( $\pi \alpha \alpha_{\alpha}$

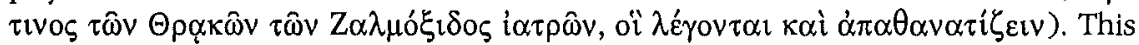
Thracian said that the Greeks were right in advising as I told you just now:

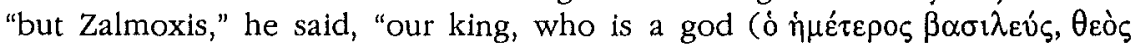
$\omega ٌ v$ ) says that as you ought not to attempt to cure eyes without head, or head without body, so you should not treat body without soul..." (translation by W.R.M.'Lamb).

Strabo gives his own version of the legend of Zalmoxis, ${ }^{126}$ whom he calls Zamolxis. After having been Pythagoras' slave, Zalmoxis arrived to Getae, and impressed them with his mantic talents. He became the king's co-regent, and became the priest of the most veneered god of the Getae. Later, Zalmoxis was declared a god. He lived alone in a cavernous place ( $\dot{\alpha} v \tau \rho \hat{\omega} \delta \varepsilon^{\prime} \varsigma$

"Dualistic Aspects of Thracian Religion," HR 10 (1971), p. 228-233; W. BurkerT, Lore and Science in Ancient Pythagoreanism. Translated by E.L. Minar, Jr., Cambridge, Mass., 1972, p. 156-159; I.H. CRIşAN, Burebista and His Time, Bucharest, 1978, p. 228-232.

122 For Greeks sending messages to gods, see PFister (cit. n. 119), p. 1114-1115.

123 BURKerT (cit. n. 121), p. 157.

124 156d-157b. For a discussion of the whole passage, see VAN DER BEN (cit. n. 119), p.11-19. For its place in the Platonic theory of soul, see M.-F. HazeBrouce, La folie bumaine et ses remèdes : Platon, Cbarmide ou De la Modération, Paris, 1997, p. 108-123.

125 The verb ( $\alpha \pi \alpha \theta \alpha v \alpha \tau i \zeta \xi \varepsilon v$, rather than more common $\alpha \theta \alpha v \alpha \tau i \zeta \varepsilon \imath v)$ emphasizes the cultic action performed in order to make one immortal (LINFORTH, o.c., 22-23; BIANCHI, cit. n. 121, p. 232).

126 VI, 3, 5. 
$\tau$ (wpíov), ${ }^{127}$ seen only by the king and his own attendants. The cave, as well as the mountain where it was located, became sacred, and since then the Getae always have such a councilor to the king, whom they deem divine. Strabo also mentions that when Byrebistas struggled against Julius Caesar, the job of the divine priest and king's councilor was performed by

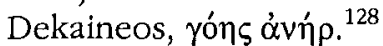

Thus, the Thracians, and among them the Getae most of all, worshiped Zalmoxis, apparently a god or a daimon, whose high priest-king seems to have been considered his substitute on earth. Zalmoxis endowed his priests with the power of healing, and they were known as physicians-i $\alpha \tau \rho o$ i. The interpretatio Graeca of Thracian ideas on immortality demonstrates that the cult of Zalmoxis involved a belief in the blissful postexistence, and certain initiatory rites: in fact, Hellanicos ${ }^{129}$ calls the rites introduces by Zalmoxis initiations $(\tau \varepsilon \lambda \varepsilon \tau \eta \dot{n})$.

Vegetarian commandments of Zalmoxis, his katabasis, and above all the doctrine of immortality induced the Pontic Greeks to link him with Pythagoras already by the fifth century. The legend about Pythagoras' descent to Hades existed at a fairly early date: ${ }^{130}$ it was known in the third century B.C. to Hieronymos of Rhodes. ${ }^{131}$ Hermippos of Smyrna ${ }^{132}$ tells a story of Pythagoras' descent to an underground chamber: living here, he received information on current events from his mother, and after some time made his appearance in the assembly, thin as a skeleton, claiming that he returned from Hades. ${ }^{133}$ W. Burkert argues a convincing case, demonstrating that the katabasis story, misunderstood by Hermippos, belongs to the archaic core of Pythagoras' legend. ${ }^{134}$ Pythagoras' mantic abilities, magical healing, and other extraordinary traits ${ }^{135}$ facilitated the comparison between the Greek sage and the Thracian daimon.

127 Here, as well as in Herodotus' testimony, there can be no doubt that Zalmoxis' abode is subterranean. BURKERT's (cit. n. 121, p. 159) assumption that Strabo and Herodotus meant that Zalmoxis lived on the holy mountain, remains ungrounded.

128 For Byrebistas and Dekaineos, see EliADE (cit. n. 119), p. 57-61; R. Vulpe, Studia Thracologica, Bucarest, 1976, p. 62-68.

129 FGrH 4. F 73 Jacoby.

130 ROHDE (cit. n. 5), p. 601.

131 Diog. LaerT., VIII, 21; 38, $c f$. Burkert (cit. n. 121), p. 155.

132 Diog. LAERT., VIII, 41; schol. Soph., Electra, 62.

133 BURKERT (cit. n. 121), p. 156.

134 Burkert (cit. n. 121), p. 159; I. LÉvy, La légende de Pythagore: de Grèce en Palestine, Paris, 1927, p. 29.

135 Iamblich., De vita Pyth., 19, 28; Diog. Laert., VIII, 11-12; Ael., Var. Hist. II, 26; IV, 17; cf. P. Corssen, "Der Abaris des Heraklides Ponticus," RhM 67 (1912), p. 30-38; Lévy (cit. n. 134), p. 40-42; M. DetIENNe, La notion de daïmôn dans le pythagorisme ancien, Paris, 1963, p. 69-70; BURKeRT (cit. n. 121), p. 141-143, 160. 
The myth of Zalmoxis' descend into an underground chamber or a cave and his priest's habitation in such a cave reveals a cultic phenomenon similar to those attested in Boeotia and Thessaly. However, in Thrace the daimon's presence in his cave was conceived and staged in a naturalistic form. Rather than to encounter the deity in dreams or in a trance, like in Tricca, Lebadea, and Oropos, the Thracians had his representative on earth alive, dwelling in a cave, but almost invisible, that is, seen only by the king and a few attendants.

\section{Rhesos}

In Euripides' Rbesus, ${ }^{136}$ the Muse, the mother of the slain Thracian king, predicts that although she will never see her son again, he will live, hidden in a cavern, a spirit in a human form (antbropodaimon). This description is strongly reminiscent of Zalmoxis. ${ }^{137}$ The Muse calls her son a cousin and a friend of Orpheus, ${ }^{138}$ and hints at an association with Orpheus, comparing Rhesos with a Thracian prophet of Bacchos, "revered as a god by those who know (the truth)."139 The exceptional future predicted to Rhesos by his

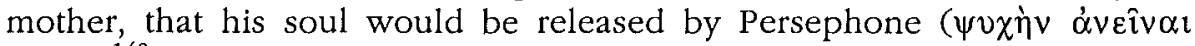
$\left.\tau 0 \hat{0} \delta^{\prime}\right),{ }^{140}$ is uttered in a monologue referring to the mysteries of the Two Goddesses. However, the initiates in the Eleusinian mysteries have never been promised to continue their life in an underground shelter. ${ }^{141}$ The Thracian king's destiny as foreseen by the Muse is reminiscent of Amphiaraos and Trophonios, who were saved by gods from disgrace and death by means of hiding them under the earth. The word antbropodaimon ${ }^{142}$ and a comparison to a prophet imply that in the eyes of Euripides Rhesos enjoyed a status "in between" a man and a deity. The poet used the hybrid word and the allusion to the Eleusinian mysteries in order to render the strange phenomenon of a mortal's ${ }^{143}$ subterranean existence comprehensible to his Athenian audience.

136 V. 962-973. For the controversy on the date of Euripides' play, see J. GEFFCKEN, "Der Rhesos," Hermes 74 (1936), p. 394-408 (suggesting the 4th cent.), W. Ritchic, The Autbenticity of Rhesus of Euripides, Cambridge 1964 (suggesting 437 as terminus ante quem).

137 A.D. Nock, "The End of the Rhesus," CR 40 (1926), p. 184-186.

138 Eur., Rhes., 944, 966.

139 V. 972-973, cf. P. Perdizet, Cultes et mythes du Pangée, Paris/Nancy, 1910, p. 16, 2728; W. LEAF, "Rhesos of Thrace," JHS 35 (1915), p. 6. For an analysis of these verses, see Nock (cit. n. 137); C. Plichon, "Le Rbésos et l'orphisme," Kernos 14 (2001), p. 17-18.

140 V. 965.

141 Cf. Plichon (cit. n. 139), p. 15. This consideration alone provides a sufficient reason to reject Leaf's theory, according to which the aim of the Rbesos was to invent a mythical link between the Thracian hero and the Eleusinian mysteries, hence, between the hero and Athens.

142 On this hapax see Plichon (cit. n. 139), p. 14-16.

143 In fact, the description of Rhesos' shining golden arms and majestic horses in the Iliad (X, 435-445; 545-550) and in the Rhesos (300-309) hints at the divinity of the Thracian 
Philostratos describes Rhesos' bieron in the Rhodopi: animals came there voluntarily, to be sacrificed on Rhesos' altar, ${ }^{144}$ Rhesos was also considered a healer: he removed pestilence from the mountain where he lived after his death. ${ }^{145}$ This report is given a propos a discussion of the activities of Protesilaos who remained alive notwithstanding his death in Troy, ${ }^{146}$ and in a paragraph listing other persons who remain lively after their demise: Amphiaraos, Amphilochos, and Maron, who even showed himself to farmers in his native Ismaros. ${ }^{147} \mathrm{~A}$ first- or second-century $\mathrm{AD}$ inscription from Eion (Ainos), the sea-port of Amphipolis, mentions an official image of Heros Propylaios, that had prophylactic qualities. ${ }^{148}$ Notably, already in the sixth century Hipponax called Rhesos Aivetôv $\pi \alpha \dot{\alpha} \lambda \mu \nu \varsigma$, the ruler of Eion. ${ }^{149}$ In fact, Rhesos' father in the Iliad is named Eioneus. ${ }^{150}$ Protection of the city would fit the hero who cleansed his land of pestilence.

A Greek-style cult of Rhesos was established in Amphipolis by the Athenians in 437, when in order to attain the protection of the local deity for their newly founded colony and following an oracle's advice, they brought

king (P. Wathelet, "Rhésos ou la quête de l'immortalité," Kernos 2 [1989], p. 227, 230231). For a discussion of Rhesos' mythology, see Ph. Borgeaud, "Rhésos et Arganthoné," in Ph. Borgeaud (ed.), Orphisme et Orphée. En l'bonneur de J. Rudhardt, Geneva, 1991 (Recbercbes et Rencontres, 3), p. 51-59.

144 Philostr., Heroic., 149; G. Seure, Le roi Rhésos et le Héros chasseur," $R P b 54$ (1928), p. 120.

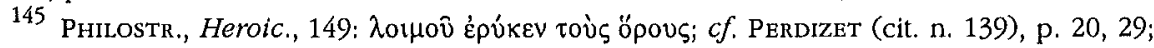
SEure (cit. n. 144), p. 121-122.

146 Heroicus passim, esp. 130; לṇ. Proteslaos, a hero whose home was in Phthiotis (Il. II, 695-710; Strabo, IX, 5, 7, 10, 14), although killed by the Trojans ( $l . . \mathrm{XV}, 705)$, is said to have been allowed to leave the Hades for a short while (Apollod, Epit., 3, 30; Hygin., 103). He had a sanctuary in the Chersonesos, where his grave was shown (HER., IX; 116; STRABO, VII, fr. 51; schol. Lycophr., 245). The hero was also a healer (Heroic., 148).

147 In the Odyssey (IX, 39-50, 196-211), Maron is a priest of Apollo in the land of the Thracian Kikones.

${ }^{148}$ G. SEure, "Étude sur quelques types curieux du cavalier thrace," $R A 14$ (1912), p. 388 .

149 Fr. 41 West. Seure (cit. n. 144), p. 112-114; 122; Perdizet (cit. n. 139), p 14; Leaf (cit. n. 139), p. 2. For the identification of the Hero depicted on some ex-voto from Thrace with Rhesos, see SEure, l.c., p. 128-129; Perdizet (cit. n. 139), p 21. Many relief representations of the Thracian Hero were discovered in caves (G. Kazarow, Die Denkmäler der Thrakischen Reitergottes in Bulgarien, Budapest, 1938, p. 5), which is suggestive of Rhesos' underground dwelling.

${ }^{150} \mathrm{Il} . \mathrm{X}, 435$, whereas in the Rbesos $(394,920,928)$ he is called the son of Strymon the river god, and in Servius' commentary on the Aeneid ( $I$, 469) the son of Hebrus, another river god. Although, as LeAf (cit. n. 139), p. 1, observes, Eioneus, literally 'Shoreman,' is a stock name in mythology, there is no ground to doubt the connection between Eioneus and Strymon, because the town of Eion was located at the mouth of the river. Leaf's ( $O P$. cit., p. 2) statement that Rhesos is "cut off from all local ties, without any bonds to cult and myth" contradicts the rich evidence on Rhesos' local ties and cult. 
there the hero's bones from Troy. ${ }^{151}$ This action reflects a tradition based on the Homeric version of Rhesos' death. To what extant the cult of Heros Propylaios in Eion may be viewed as a continuation of cult founded by the Athenians, rather than a local avatar of the Thracian Hero, remains unclear. In any case, Marsyas of Philippi in Thrace, Trajan's contemporary, mentioned a mnemeion of Rhesos on a hill near Amphipolis. ${ }^{152}$

Rhesos' name may mean "king," deriving from the same root as rex. ${ }^{153}$ Thus, he appears to be a Thracian primeval king, who enjoyed a cult at least in the first centuries $\mathrm{AD}$, and apparently also earlier. ${ }^{154}$ The comparison with the Bacchos' prophet suggests that Rhesos' abode on the Mount Pangaios functioned perhaps as an oracle. Thus, as divine kings and prophets living below the earth, Rhesos and Zalmoxis represent the same pattern of religious thinking; Zalmoxis was the tribal deity of the Getae, whereas Rhesos was the patron of the Edonians. ${ }^{155}$ The subterranean residence of this hero, considered a healer and a savior, was explained in an etiological myth. Its Greek version only has reached us, but it is plausible that Thracians had their own legend of Rhesos, alongside the story of Zalmoxis.

\section{Subterranean oracles and dwellers outside the Northern Balkans}

\section{Acharaca}

Strabo ${ }^{156}$ gives a detailed description of a Charonion, a cave that lies near a shrine of Pluto and Core in Caria, between Tralles and Nysa. Diseased arrived there, and either experienced priests slept in the Charonion on their behalf, and through dreams prescribed the cures, or the suppliants themselves were brought to the cave and left in quit and without food for many days, "like (animals) in a den" ( $\alpha \alpha \alpha \dot{\alpha} \pi \varepsilon \rho \dot{\varepsilon} v \varphi \omega \lambda \varepsilon \hat{\text { ) }}$. To everybody but for the sick and the priests the place was forbidden and deadly. Sometimes

151 Polyaen., Strat. VI, 53; Perdizet (cit. n. 139), p. 15.

152 Schol. in Rbes, 346, cf. Seure (cit. n. 144), p. 109; Perdizet (cit. n. 139), p. 15.

153 Tomascheck (cit. n. 121), p. 53; Perdizet (cit. n. 139), p. 17; G. Seure (cit. n. 144), p. 106-110; Poghirc (cit. n. 120), p. 196; Wathelet (cit. n. 143), p. 222; Borgeaud (cit. n. 143), p. 13, cf. V.N. Toporov, "The Thracian Horseman in an Indo-European Perspective," Orpbeus (1990) p. 51-52. For the cult of Rhesos in Thrace, see Perdizet (cit, n. 139), p. 18-20; SEURe (cit. n. 144).

154 Cicero's testimony (De Nat. Deorum III, 18) that Orpheus and Rhesus, although born by Muses, were not considered gods and enjoyed no cult (nusquam coluntur), is misleading: Orpheus' bones were preserved in Dium, in Macedonia (PAUs., IX, 30, 7-12), which implies a heroic worship. Rhesos' heroic cult in Troy and later in Amphipolis has already been mentioned. Cicero, who ignores Orpheus' worship in the musician's native country on the periphery of the Classical world, equally takes no notice of Rhesos' cult in Thrace.

155 ROHDE (cit. n. 5), p. 143.

156 XIV, 1, 43. 
the inquirers heeded to their own dreams, but usually they received guidance from the priests, who also initiated them into the mysteries. Acharaca was also a place of an annual festival. In a nocturnal ceremony, the participants could see and hear "all theses things," while at noon nude boys and epheboi led a bull into the cave and left it there to die instantly.

In Acharaca we find a combination of a iatromanteion where at least some of inquirers seeking cure experienced direct contact with the divinity, obviously in a state of delusion inflicted by the frightening surroundings and the long fast, enhanced by their malady. Presumably all the sick were initiated into the mysteries, which were also celebrated in the annual nocturnal rite. The use of the word $\varphi \omega \lambda \varepsilon$ có (as well as $\theta \alpha \lambda \alpha \mu \eta$ in the case of the Trophonion ${ }^{157}$ ) may hint at the temporal identification of the initiands with beasts lurking in a den. Transition rites are indicated by the involvement of the nude youths.

Strabo reports the existence of three Charonia in the vicinity of the Meander: at Hierapolis, at Acharaca and the Aornum) near Magnesia, and explains the multiplicity of cave oracles by soil conditions, favoring the formation of caves. ${ }^{158}$ Magnesia on the Meander is a colony of the Magnesia of Thessaly. ${ }^{159}$ Three major elements of the cult in Acharaca, the emphasis on healing, the prominence of a cave and of rites de passage, as well as the equation of participants in the ritual with animals, are present in the cult of Chiron on the Mount Pelion in Thessalian Magnesia. ${ }^{160}$ Direct contact with the divine experienced by the inquirers in an oracular cave is characteristic of the Boeotian cults, as well as of the Asclepeion in Thessalian Tricca, but the essential role of the priests indicates perhaps an involvement of an additional tradition. It is not impossible that the Aeolian settlers brought this cult pattern to the Meander valley, where they found plenty of caves, some of them probably housing local cults. In any case, the oracular shrine described by Strabo functioned almost entirely in conformity with the Aeolian prototype.

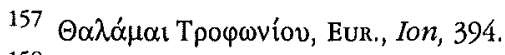

158 Strabo, XII, 8, 17, cf. XIV, 1, 11. In fact, Pausanias reports the existence of another cave near Magnesia, sacred to Apollo (X, 32, 6).

159 Strabo, XIV, 1, 11.

${ }^{160}$ Chiron was most famous as the inventor of medicine (Plut., Mor., 647a; Hygin., Fab., 138; Suda, s.v. Xeípov; Serv. comm. in Ver. Georg. III, 550), or as a most prominent physician, who knew all the illnesses and their remedies (PIND., Pyth. III, 83-95 with schol.). His dwelling in a cave on the Mount Pelion is mentioned in numerous sources, e.g. PInd., Pyth. III, 63, cf. Philippson (cit. n. 110), 137-155. Youths from most distinguished Magnesian families came annually to Chiron's cave on Mount Pelion, wearing new lambs' skins, which means that they were brought there as sacrificial victims, disguised as young animals (Heracleides apud [Dikaiarchos], GGM I, 107, cf. StÄhlin (cit. n. 105), p. 42; Philippson (cit. n. 110), 147; P. BONNECHere, Le sacrifice bumain en Grèce ancienne, Liège, 1994 [Kemos, suppl. 3], p. 147). 


\section{Althaimenes of Rhodes}

Althaimenes was also granted a disappearance under the earth by the gods, after he had involuntary killed his father. ${ }^{161}$ This Althaimenes, the son of a Cretan king Katreus, was the heroic ktistes of the island and the mythical founder of the cult of Zeus Atabyrios. ${ }^{162}$ Nothing is known of Althaimenes' talent as a seer, but his heroic cult on Rhodes is attested both by Diodoros and by an inscription implying that he was an eponymous hero of a political division named Althamenis. ${ }^{163}$

The myth of Althaimenes is the only tale of disappearance below the earth located outside the limits of the Northern and Central Balkans. It may however be suggested that this tale was connected with the Thessalian tradition. Althaimenes, son of Keisos, a mythical founder of Cretan cities, ${ }^{164}$ is also said to have established the three cities of Rhodes. ${ }^{165}$ This correspondence may imply that we deal with two versions of the same hero's life story. ${ }^{166}$ Althaimenes son of Keisos is repeatedly called Argeios, ${ }^{167}$ whereas R. Drews argues that the epic Argives originate from the Pelasgic Argos in Thessaly, rather than Argos in the Peloponessos. ${ }^{168}$ This explanation, resting as it is on two suppositions, is indeed shaky, but if it is correct, all the myths of subterranean dwellers are associated with the Northern Balkans.

\section{Conclusions}

Myths of underground demise were told about a number of figures, who did not perish below the earth either because they were immortal, or due to gods' will. A combination of mythological and historical evidence on the cults of subterranean dwellers and their biographies reveals a pattern based on a series of common features. Seldom attested in full, these traits produce however a basis for attribution of several phenomena to the same mythocultic type.

\footnotetext{
161 APOLLOD, III, 2, 2.

162 DioD., V, 59.
}

163 Diod., V, 59; IG XII 1, 695, col. I. 19, cf. Schreiber, "Althaimenes," Roscher, I, 1 (1884-86), p. 260-261; Roнde (cit. n. 5), p. 104; id., "Zur Chronologie der griechischen Litteraturgeschichte," RbM 39 (1881), p. 432-433.

164 STRABO, X, 4, 15; cf. XIV, 2, 6

165 Conon, FGrH 26 F 47 Jacoby.

166 Contrary to RoHDE's opinion (cit. n. 163, p. 432-433), who argued that the two are distinct personages.

167 Cf. n. 164.

168 "Argos and Argives in the Iliad," CPb 74 (1979), p. 111-135; id., The Coming of the Greeks, Princeton, 1998, p. 190-194. On the relationship between Thessaly and Crete, and on the Thessalian genealogy of the Cretan king Idomeneus, see E. Grumach, "The Coming of the Greeks," BRL 51 (1968-69), p. 412-413. 
Etiological legends narrating stories of disappearances into chasms, caves, and subterranean chambers vary from place to place, but in most cases vanishing in a chasm is a divine blessing, granted to a mortal hero to save him from imminent death or disgrace, and endowing him with immortality. ${ }^{169}$ The problem is not "that cult aition has been confused with cult," as A. Schachter assumes. ${ }^{170}$ These tales look like explanations invented to account for the daimon's life in the depth of the earth: myths that give reasons for an ancient cult type. ${ }^{171}$ Two elements are distinctive, the daimons' immortality and their subterranean existence.

The immortality of these characters is of a very peculiar kind. They are not transferred to Elysion or to the Olympus, but stay forever in the place where the earth swallowed them, and they never appear in the realm of the living unless in a dream or revelation on this place. ${ }^{172}$ Their status is that of absolute liminality: they belong neither to the living nor to the dead nor to the gods. Thus, they are able to act as mediators between the worlds, disclosing to the living secret knowledge normally confined to the dead or to the gods.

These daimons are confined to the place of their worship. The sanctuaries of Amphiaraos and Trophonios were in the vicinity of their respective poleis; Asclepios, the only one among these characters that was promoted to the rank of a panhellenic god, had an ancient incubation oracle in his native Tricca, whereas Zalmoxis and Rhesos, living inside the mountains sacred to them, were presumably patrons of Thracian tribes. Thus, each of them was a master of the land, in the depth of which his abode was hidden. ${ }^{173}$

In most cases these characters have a healing aspect, either acting as healers and purifiers during their life time, or giving oracular responses on medical matters after their death. Some of these daimons were believed not only to possess healing powers, but also to endow people or their souls with

169 In this respect, these figures obviously differ from personages hurled into the underground world a punitive measure. In the Archaic poetry, Tartaros is a place of confinement for the immortals only: Titans are actually imprisoned there, while the gods are threatened by Zeus that their lack of obedience would be punished by hurling into Tartaros. Human wrongdoers are penalized elsewhere. See Hes., Theog., 713-745, 851; Hoм., Il. VIII, 478-481, XIV, 203, 273-279, XV, 225), cf. GANTZ (cit. n. 98), vol. 1, p. 44, 128129. Tartaros becomes a place of punishment for human transgressors no earlier than in Plato's Gorgias (523b), see Gantz, ibid. 131.

170 Schachter (cit. n. 8), vol. 3, p. 71.

171 Rohde (cit. n. 5), p. 93. Legends about holy people who live in the depth of mountain caves, are attested throughout Eurasia and even America, and must have developed independently (ROHDE, p. 106).

172 RoHDe (cit. n. 5), p. 91.

173 And not avatars of the same god, whose original name had been forgotten, and who was given different names in each of his sanctuaries, as ScHACHTER (cit. n. 8, vol. 3, p. 71) assumes. 
immortality. Occasionally episodes in the mythic biographies of subterranean daimons suggest other magic and cultic activities. In several cases initiation ceremonies are either explicitly mentioned or hinted at.

Divination by means of incubation above abodes of a subterranean daimons or descend to their caves was initially based on the idea that the daimon was physically present in the place. ${ }^{174}$ The association of such oracles with gods, who could, at least in theory, move where they would, appears to have evolved at a later stage, as an imitation of the original cult type in places where no local legend of a subterranean dweller was ready to be adopted as an aition.

Notwithstanding the experience of trance by some inquirers in Lebadea and in Acharaca, healing and initiatory practices, as well as the occurrence of magical motifs in life legends of some daimons, this cult type can be associated with shamanism ${ }^{175}$ only to a certain extent. Important elements of the shamanic complex, ${ }^{176}$ such as the ascension to the heaven, the ability to communicate at will with the world beyond, ${ }^{177}$ as well as the shamanic vocation and trial, are absent. Ecstatic experience is too ubiquitous to justify a classification of a phenomenon as shamanic. However, distinct cultic practices focusing on psychic transformations are related, all of them belonging to the broad category of altered states of consciousness, and may therefore share notions and actions. ${ }^{178}$ Thus, despite some common features, the cult type focused on subterranean daimons is to be distinguished from the cultural pattern represented by personalities revealing essential shamanic traits, such as Orpheus, Abaris, and Aristeas. ${ }^{179}$ Sensitive to this distinction,

${ }^{174}$, ROHDE (cit. n. 5), p. 92.

175 As some authors do, such as Dodds (cit. n. 23, p. 144, 166), HANi (cit. n. 50), and to a certain degree Bonnechere, "La scène... (cit. n. 28), p. 479. Eliade (cit. n. 119, p. 43) observes that the rites connected with Zalmoxis are not of shamanic nature.

176 For a discussion see e.g. M. EliAde, Shamanism. Archaic Techniques of Ecstasy. Translated by W. R. Trask, Princeton, 1974; Atkinson (cit. n. 104).

177 In this respect, Asclepios is an exception: his numerous acts of resuscitation (Edelstein, cit. n. 86, vol. 1, Nos. 66-93) imply that he was able to descend to Hades at will.

178 E. Bourguignon (ed.), Religion, Altered states of Consciousness, and Social Change, Columbus, 1973; id., Possession, San Francisco, 1976. On the contrast between katabasis and ecstasis see CLARK (cit. n. 30), p. 71.

179 DetienNe (cit. n. 135), p. 82; Dodds (cit. n. 23), p. 144; BURKERT (cit. n. 102), p. 140165; D. Metzler, "Zum Shamanismus in Griechenland," in D. Metzler, Ch. MÜllerWirth, B. Otro (eds.), Antidoron Jürgen Thimm, Karlsruhe, p. 75-82; M.L. West, The Orpbic Poems, Oxford, 1983, p. 149; Ch. H. KAHN, "Religion and Natural Philosophy in Empedocles' Doctrine of the Soul," $A G P b 42$ (1960), p. 32 (diffidently); for a denial of such association see L. ZнмUD, Wissenscbaft, Philosopbie und Religion im früben Pytbagoreismus, Berlin, 1997, p. 108-116. For shamanic elements in Greek culture, see the illuminating discussion by P. KINGSLey ("Greeks, Shamans and Magi," Studia Iranica 23 [1994], p. 187-198). 
Greek authors usually separated subterranean dwellers and quasi-shamanic figures in discrete groups. ${ }^{180}$

Countries of the Northern Balkans, from Thrace to Thessaly to Boeotia, appear to have shared similar patterns of chthonic cults, involving a myth of a daimon's underground dwelling and his patronage of initiatory and/or divination rites. The occurrence of a compatible cult in Caria may be related to a Thessalian prototype or prototypes. The distribution of this cult type seems to reflect the population movement from the Northern Balkans to Thessaly and southwards to Boeotia, and of further migration to Asia Minor. ${ }^{181}$

The perplexing status of the immortal subterranean daimons who remained outside all the usual Greek categories, the artificial attachment of cult aitia to their cults, and connection of the cave-dwellers to the country of their worship invite a hypothesis of their pre-Greek origin, while the evidence from Thrace and the predominant distribution in Northern and Central Greece indicate the possible direction of dispersion of this cult type. However, a definite statement on this matter can be made only as a result of a research involving an analysis of archaeological, linguistic and other data pertaining to the intricate subject of "the coming of the Greeks," which is beyond the scope of this paper.

Department of History

Yulia Ustinova Ben-Gurion University of the Negev

P.O.B. 653

BEer-SHEva 84105

180 For a list of these registers, see Burkert (cit. n. 102), p. 147. An interesting subject is the connection between the cultic pattern involving an experience of direct contact with the divine inside an underground chamber, and the katabasis stories told about some early Greek philosophers. Its discussion would have lead us beyond the limits of this paper.

181 Cf, an identical distribution scheme suggested by SCHACHTER ("A Boeotian Cult...", cit. n. 30, p. 14) for another pattern of oracular cult, focused on a hero and a nymph, and involving male prophets, inspiration by use of a sacred spring. 